\title{
What can we expect of an early start to foreign language learning in Europe today?
}

\section{Janet Enever}

Umeå University, Sweden

In the light of the global trend towards an ever-earlier start to foreign language learning, this paper summarises current knowledge on pre-primary provision for early language learning in Europe, highlighting the challenges of equitable provision for this non-compulsory education sector. The discussion draws on data evidence from the ELLiE study (2006-2010) to propose that much remains still to be done in terms of quality provision even in those countries with a compulsory start age of six or seven years.

Keywords: early start to foreign language learning, pre-primary provision for early language learning, ELLiE study, non-compulsory education sector, quality provision

\section{Introduction}

Provision of early second and foreign language education in Europe has steadily risen since the early 1990s, increasingly becoming a priority during the 21 st century following the publication of the Lisbon Strategy (2000). Many recommendations, reports and statistical analyses have supported and, no doubt, contributed to the lowering of the start age across member countries. Figure 1. summarises the extent of the changes since 1990, indicating that almost all member states now have a compulsory start age of either $6 / 7$ years or $8 / 9$ years.

\begin{tabular}{|l|c|c|c|}
\hline \multirow{2}{*}{ Year } & \multicolumn{3}{|c|}{$\begin{array}{c}\text { Compulsory start age } \\
\text { (for the 28 current EU member countries) }\end{array}$} \\
\hline & 7 yrs. or below & $8-9$ yrs. & $10-11$ yrs. \\
\hline 1990 & 2 & 1 & 25 \\
\hline 2013 & 14 & 11 & 3 \\
\hline
\end{tabular}

Figure 1: EU member countries FL start age policy ${ }^{1}$

Recent reports from European expert groups have acknowledged the effectiveness of this shift in policy (Commission of the European Communities, 2007; Eurydice, 2012) and have now begun to address questions of introducing additional languages at the pre-primary phase of education (pre-school/kindergarten/nursery). In the following sections I will firstly discuss pre-primary provision of second/foreign languages, then school provision and finally discuss those weaknesses in the system which still need to be addressed.

\footnotetext{
1 The three countries currently with later compulsory policies of 10/11yrs. are Hungary, England and Netherlands. England plans to alter the compulsory policy to 7 years from September 2014 (For further detail see Eurydice, 2012. 26).
} 
What can we expect of an early start to foreign language learning in Europe today?

\section{Pre-primary second and foreign language provision}

Accurate data for pre-primary provision and the inclusion of second and/or foreign languages in the curriculum is difficult to collate at a European level, given the noncompulsory nature of provision for the age group two-five/six years in a number of countries and hence the varied curricula frameworks that co-exist. The Strategic Framework for European Cooperation in Education and Training (ET 2020) specifies a provision target for 2020 whereby: "At least $95 \%$ of children aged between four and the age in which compulsory primary education starts should participate in early childhood education" (Council of the European Union, 2009).

As a starting point for establishing some kind of baseline on current trends in providing early language learning (ELL) within this sector, a European expert group was set up in 2009 to review current practices and establish some guidelines (European Commission, 2011). Notably, the Review focused on the provision of both early second/ foreign languages and the early teaching of language of instruction / second language for children with a minority or migrant background. Inevitably, with such varied provision, the review noted that the inclusion of FLs in curricula frameworks varied considerably. However, it highlighted evidence that demand for provision has been rapidly rising from parents. Given the limited focus of this paper I will not explore the various discussions of good practice in the Policy Handbook, but will briefly summarise the three main challenges for the introduction of ELL in Europe, as highlighted in the Handbook.

1. Equity - the Handbook reports that availability of FLs may not be uniform across all geographical regions and socio-economic groupings. In addition, staff may not be well-qualified or there may simply be a lack of sufficient staff for satisfactory provision. This variation in both quality and provision may result in a lack of equity for all pre-primary children.

2. Quality and consistency - Whilst arguably, pre-primary language education may offer all children "a good start to the emotional, social and cognitive development resulting from language exposure" (European Commission, 2011. 10.), in practice, responsibility for establishing quality $F L$ education for this sector is often lacking in cohesion. Responsibility may be divided between local and central authorities; early childhood and school education or general education and language education. Evidence suggests that there remains much to be done in terms of cooperation between authorities if quality and consistency is to be established.

3. Continuity - Providing continuity across school phases is a vital part of ensuring that FL learners achieve progression. Given the varied provision of FLs at the pre-primary phase it is not yet feasible to achieve continuity from pre-primary to compulsory schooling in many contexts. The added complexity of the range of languages that might be offered in different pre-primary classes may further limit satisfactory transition since schools may simply be unable to support continuity for classes which previously have been introduced to a variety of FLs. The addition of language awareness activities might contribute to establishing an inclusive approach to FLs in the early stage of entry to primary schooling, but it seems unlikely that it would be feasible to fully support continuity across a range of languages throughout the primary years of schooling.

Whilst the challenges outlined above represent the views of national experts regarding the current provision of L2/FLs in the pre-primary sector of education across Europe, they might equally be considered as challenges still in evidence in European primary schools today. The following section will draw on empirical evidence from a study of early language learning in Europe (ELLiE) to identify aspects of current provision that still remains to be addressed. 


\section{Primary FL teaching and learning in Europe (the ELLiE Study)}

As indicated in Figure 1, ELL has a substantial history in Europe. Mihaljevic Djigunovic (2013) reports from Vilke (2007) that "beginnings [in Croatia] can be traced back to the first half of the 20th century". From the 1950s to 1980s a number of pilot studies were carried out in various European countries, resulting in some regions and individual schools establishing FL provision for the age group 9-11 years or even earlier. The introduction of national policies for compulsory FL provision at primary level was initiated in the 1980s and steadily grew in importance throughout the 1990s and first few years of the 21st century. Following the Action Plan (Commission of the European Communities, 2003), a review of current research was commissioned by the European Commission (Edelenbos, Johnstone \& Kubanek, 2006) which aimed to identify where weaknesses in current provision for early language learning in schools still remained. This publication, together with other reports published during this period, were instrumental in the European Commission (EC) decision to support a transnational longitudinal study of foreign language learning in primary schools across Europe (ELLiE study, 2007-2010). It should be noted also that, prior to the EC award period, the British Council had partly funded a smaller scale scoping study in six of the seven country contexts, enabling the research team to assess the potential for conducting a larger scale study. Data from this phase was later combined with some sections of more recent analyses to provide evidence across a full four years of the children's FL development.

In establishing the ELLiE study, the aim was to explore children's FL learning in ordinary state school classrooms where the intensity of FL provision was limited to between 45-120 minutes per week (1-3 lessons). The benefit of conducting a large-scale study (1400 children, their parents, teachers and school principals), across seven European country contexts (Croatia, England, Italy, Netherlands, Poland, Spain and Sweden) was that it would be possible to provide statistically significant evidence which would be likely to reflect the issues arising in many parts of Europe. The longitudinal framework of the study allowed the research team to track the progress of individual learners over time, recording how motivation fluctuated and revealing how this might affect progress from year to year. As such, this framework broke new ground in the field, providing many new insights which have already stimulated further research in other European contexts, drawing on the model of the ELLiE study.

\section{Start age and language choice}

Country contexts selected for the study reflected regions or countries where schools had introduced a first FL from age six or seven years, with English being the chosen first FL in six countries, whilst French and Spanish were represented in the case of England.

\section{Language aims and achievements}

National policy documents were surprisingly similar in the aims they outlined for these young children. Six of the seven countries substantially focused on language targets, with only limited references to the wider benefits of early language learning. Only Croatia appeared to prioritise the broader educational aims over possible linguistic targets, describing these as: "based on a multisensory and holistic approach and grounded in situation-based oral communication" (ELLiE team, 2010). It was notable that all seven countries expressed language aims in terms of the Common European Framework for 
Languages (CEFR) (Council of Europe, 2001) with England, Spain, Croatia, Poland and Sweden citing $A 1$ to be achieved by the end of the primary years, whilst Italy identified the more challenging goal of A1+ and Netherlands considered A2 to be achievable. This norm referencing can now be viewed as a fairly standard practice throughout Europe $(H u, 2013)$, despite its inappropriacy for describing children's language abilities, given its failure to take account of their developmental characteristics (Szpotowicz, 2013. 183.).

With regard to outcomes by the age of 10-11 years the Study revealed a wide range of actual achievements both within and across contexts. A variety of research instruments were designed to record progress, with administration conducted at annual intervals, across all seven country contexts, over the four year period of the study. Lesson observations were also scheduled throughout the study, gathering evidence of how the nature of task types, classroom management and the wider social environment impacted on learning. The complexities of these findings are too lengthy to discuss in this brief overview article, however, three data samples are included here (Figure 2) to illustrate average children's abilities in oral interactions during a task discussing classroom activities represented in a given picture. Children were invited to choose one child from the picture, asking the researcher to guess which child they were thinking of. The circled sections of text show how some children were able to produce a significantly more complex response to questions, than others. It is evident from the student in context $\mathrm{C}$, for example, that they were not able to continue with the second phase of the task at all as they struggled to formulate any questions to ask the researcher, despite the model provided by the researcher during the first section of the task. Nonetheless, it should be acknowledged that all three respondents have more or less succeeded in communicating - the aim of this task.

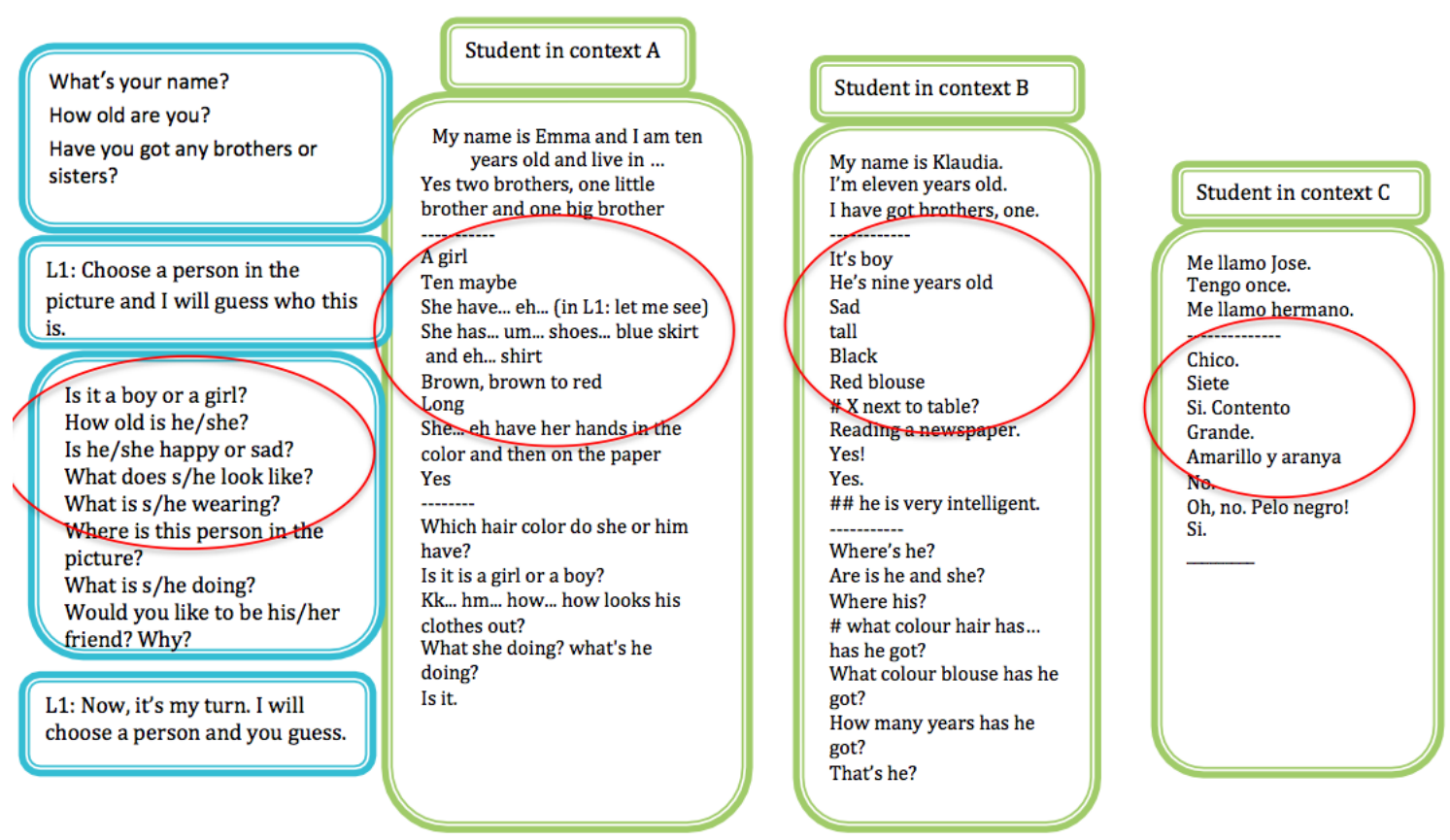

Figure 2: Oral interaction task, ELLiE study (age 10-11 years)

(Szpotowicz \& Lindgren, 2011. 137)

Overall, as Szpotowicz and Lindgren (2011. 141.) report, "the average learners across ELLiE countries have approached A1 level in their oral and aural skills". This sample represents achievement of the A1 level for listening 'I can understand familiar words and very basic phrases when people speak slowly and clearly' and A1 for talking 
with someone 'I can use simple phrases and sentences and I can also talk to someone in a simple way, asking and answering'.

A further interesting finding regarding language achievement was the evidence of children's holistic approach to language learning at this age. Data analysis of listening, speaking and reading tasks in the final year of the study revealed a clear interrelationship across the three skills, indicating that most children had progressed at approximately the same rate in each skill, by the end of the study. Thus, the children who did well in speaking were also inclined to be good at listening and reading. However, there were some children for whom this did not apply. In such cases one or other of the language skills appeared to advance more rapidly than others. Further investigation of this factor is needed before any conclusive evidence can be presented.

\section{Motivation and attitudes to language learning}

In each year of the Study children were asked to complete a short Smiley questionnaire, providing a snapshot of how they felt about FL learning. In addition, a random sample of children from each class was interviewed to gather a more detailed picture of their attitudinal development over time. Lesson observations also took note of motivational responses during class. An analysis of this data indicated that children aged 6-7 years were inclined to view their experience of FL learning very positively - often with a whole class reporting that they enjoyed the lessons. However, by the age of 10-11 years there was notably less enthusiasm expressed by a significant proportion of children. Figure 3 provides just one example of responses to the Smiley questionnaire, comparing opinions at the beginning and end of the study.
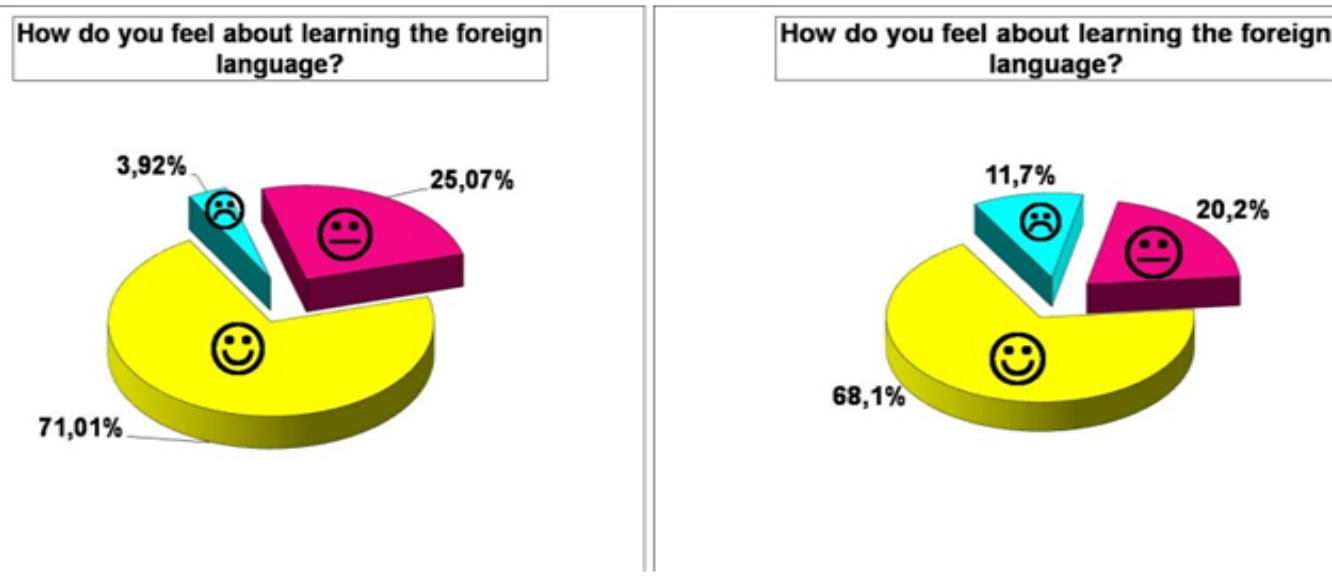

Figure 3: Children's feelings about learning FLs at the beginning and end of the Study (Mihaljevic Djigunovic \& Lopriore, 2011. 45.).

The Figure indicates that the percentage of children who felt less happy about learning the FL by the end of the Study had risen from $3.82 \%$ to $11.7 \%$. Further investigation of children's responses suggested that older children recognised the changes that had occurred in their lessons, moving from a mainly oral focus of songs, games and stories, to a heavier load which included reading, writing and learning vocabulary. For quite a number of children FL had become just another lesson, rather than an occasion for enjoyment, talking to each other and fun. This change of attitude was also evident during lesson observations and in interviews with teachers who reported on the challenge of keeping all children engaged, as they grew older. 
Children's changing attitudes were also reflected in their views on the kinds of activities that they enjoyed in the FL classroom. At an early stage of the Study games, singing and learning new words were identified as the most popular activities overall. Towards the end of the Study their popularity had declined, whilst the popularity of listening and reading had particularly increased. Notably, the enjoyment of stories was mentioned by only a few children - both in the early and later stages of learning. This may well have reflected the quite limited exposure to stories that children in some classrooms experienced. Other possible explanations may include the possibility that some children do not see the connection between enjoying stories and learning FLs, or that teachers need more guidance in how to use story effectively. Further research across a number of contexts is needed to identify possible explanations for this finding.

\section{Language exposure outside school}

The main aim of the ELLiE Study was not to compare and contrast the nature of FL learning in different countries, rather, the research team set out to build a comprehensive picture of what was happening at a transnational level across Europe. It was recognised of course that some countries had substantially more experience of $\mathrm{FL}$ teaching than others and therefore might be expected to have fully embedded effective provision for primary learners. Given the particular sample of countries participating in the ELLiE study, it was also evident from the start that children in some countries would be likely to have substantially more exposure to the FL beyond the school environment, than others. In a first attempt to try and quantify this exposure the team collected evidence of linguistic landscapes local to each of the schools. In addition, questionnaire data was collected from parents, teachers and children, asking them to report on the kinds of exposure to the FL that they experienced outside school and the FL background of parents and other carers. Collating this data revealed the extent of the different levels of exposure in each of the countries, as illustrated by Figure 4.

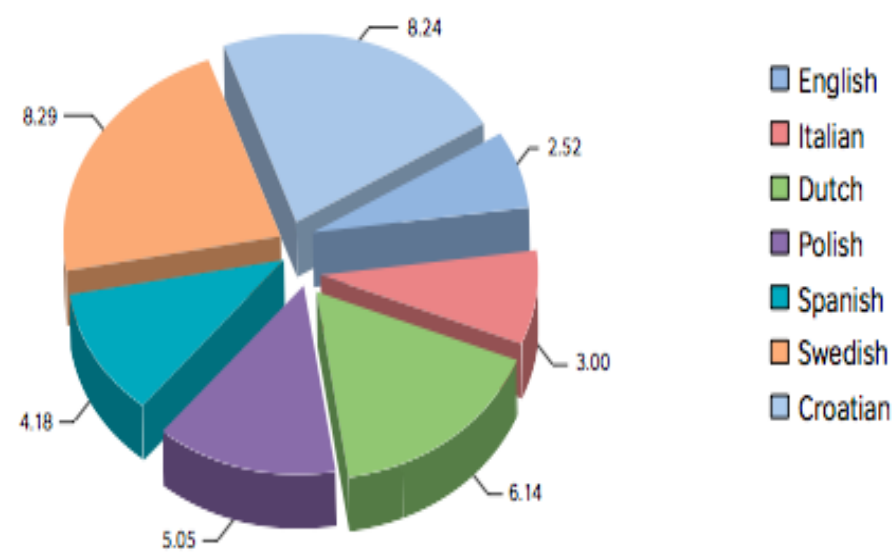

Figure 4. Mean hours of exposure each week to FL outside school (Munoz \& Lindgren, 2011. 110.)

Figure 4 indicates that children in the Swedish and Croatian contexts were exposed to a total of over eight hours per week of English, on average, whilst in other contexts the figures were considerably lower. It is important to note here that this data cannot be viewed as representative of whole countries, since the Study drew on a convenience 
sample to facilitate the efficient collection of longitudinal data. This data included children's reporting of watching films, cartoons and/or series on TV (sometimes subtitled); playing video and computer games; listening to music; reading books, magazines, comics and speaking with others in the FL. In addition, data was collected on children's use of the internet in the FL, their use of the FL on holidays abroad, the parents' educational level and their knowledge and use of the FL at work. Statistical analysis of this data when set alongside data of these children's linguistic achievements revealed the most important contributory factor to the overall development of listening and reading skills in the FL was exposure to films and TV (Munoz \& Lindgren, 2011. 112.). Whilst this analysis provides evidence of the powerful influence of such exposure, a more detailed investigation of the impact of exposure to films and TV, in comparison with other factors, would be most welcome (Munoz \& Lindgren, 2013).

\section{Creating language-rich partnerships between home and school}

As anticipated, in England children's exposure to the FLs (both French and Spanish) was very limited outside school. English in Europe today is widely understood and societal views on its importance for work and social purposes rank it more highly than the equivalent value placed on learning FLs in England (Tinsley \& Comfort, 2012). Some evidence from the ELLiE study signalled how schools might work together with parents to build a stronger network of FL exposure for children living in relatively language-poor environments, in the expectation that this might help to provide the kinds of support for language learners that is widely available in countries such as Sweden and Croatia. Ideas that schools experimented with included: inviting native speakers of the FL to spend time in the school regularly to help children appreciate the communicative potential of learning a FL; seeking out any star sports people (e.g. international footballers) and inviting them or their families into the school; sending home a weekly list of suggestions for TV programmes in the FL that children might watch (or posting these on the school website); establishing international links with schools (via the British Council, Connecting Schools Network) enabling children to exchange emails/letters, teachers to visit one another's schools or to spend time learning the FL in-country; organizing a day of activities in the FL and inviting parents into school to participate; setting up after-school sessions for parents to learn the FL themselves and other similar partnership ideas.

\section{Conclusions}

Interpreting the complex evidence of the ELLiE study is not straightforward and there remains much further analysis to be done. However, the Study has clearly revealed a number of indicators that affect high achievement. This paper has discussed aspects of motivation and attitudinal development, classroom contexts for language learning and out-of-school contexts in particular. Elsewhere, ELLiE data on the important role of the teacher and the provision of pre/in-service teacher education programmes is also emphasised (Tragant \& Munoz, 2012).

As indicated in the first section of the paper, it is currently less practical to attempt an interrogation of contexts for FL learning at the pre-primary stage, given the more varied provision and less regulated nature of the sector across Europe. However, the current trend towards an ever-earlier start suggests that this may be possible at some future date. Likely influences on the growth of this sector may include evidence from 
What can we expect of an early start to foreign language learning in Europe today?

brain studies research relating the impact on brain development that early multiple language learning may have (Mohades et al., 2012). Given the factors outlined in this paper it seems likely that early provision will continue to grow, resulting in increased demand for compulsory provision from a pre-primary phase across Europe. It is to be hoped that national funding will address those remaining weaknesses in teacher preparation and provision of resources sooner rather than later.

\section{References}

Commission of the European Communities (2003): Communication from the Commission to the Council, the European Parliament, the European Economic and Social Committee and the Committee of the Regions: Promoting Language Learning and Linguistic diversity: An Action Plan 2004-2006. COM (2003) 449 final.

URL: http://ec.europa.eu/education/doc/official/keydoc/actlang/act_lang_en.pdf (03. 04. 2013)

Commission of the European Communities (2007): Report of the High Level Group on Multilingualism Council of Europe. Luxembourg: Office for Official Publications of the European Communities.

Council of Europe. (2001): Common European Framework of Reference for Languages: Learning, teaching, assessment. Cambridge University Press, Cambridge.

Council of the European Union (2009). Conclusions of 12 May 2009 on a strategic framework for European cooperation in education and training. Official Journal of the European Union, 2009/C 119/02.

URL: http://eur-lex.europa.eu/LexUriServ/LexUriServ.do?uri=OJ:C:2009:119:0002:0010:E N:PDF (02. 04. 2013)

Edelenbos, P., Johnstone, R. \& Kubanek, A. (2006): The main pedagogical principles underlying the teaching of languages to very young learners, languages for the children of Europe, Published Research, Good practice \& main principles. European Commission, London.

ELLiE team (2010): ELLiE Policy Summary - October 2010. ELLiE Conference Presentation, Warsaw, 27th October 2010.

URL: http://www.ellieresearch.eu/docs/ELLiE_country_policy_analysis_23Jan2011.pdf (04. 04. 2013)

Enever, J. (2011, ed.): ELLiE. Early Language Learning in Europe. British Council, London. URL: http://www.teachingenglish.org.uk/publications/early-language-learning-europe (02. 04. 2013)

European Commission (2011): Policy Handbook. Language learning at pre-primary school: making it efficient and sustainable. European Commission, Brussels.

URL: http://ec.europa.eu/languages/pdf/ellpwp_en.pdf (06. 04. 2013)

Eurydice Network (2012): Eurydice: Key data on teaching languages at schools in Europe. Brussels: Commission of the European Communities. European Commission, Brussels.

URL: http://eacea.ec.europa.eu/education/eurydice/key_data_en.php (02. 04. 2013)

Hu, A. (2013): Academic Perspectives from Germany. Byram, M. \& Parmenter, L. (eds.), The Common European Framework of Reference: the globalization of language education policy. Multilingual Matters, Bristol.

Lindgren, E. \& Munoz, C. (2013): The influence of exposure, parents and linguistic distance on young European learners' foreign language comprehension. International Journal of Multilingualism, 10. 1., 105-129.

Mihaljevic Djigunovic, J. (2013): Early EFL learning in context - Evidence from a country case study. In: Sheehan, S. (ed.) British Council ELT Research Papers. 1, British Council, London, 159-182.

URL: http://englishagenda.britishcouncil.org/sites/ec/files/British\%20Council\%20WEB\%20 pdf_0.pdf (06. 04. 2013) 
Mihaljevic Djigunovic, J. \& Lopriore, L. (2011): The Learner: Do individual differences matter? In: Enever, J. (ed.), ELLiE. Early Language Learning in Europe. British Council, London, 43-59.

URL: http://www.teachingenglish.org.uk/publications/early-language-learning-europe (05. 04. 2013)

Mohades, S. G.,Struys, E., Van Schuerbeek, P, Mondt, K., Van De Craen, P. \& Luypaert, R. (2012): DTI reveals structural differences in white matter tracts between bilingual and monolingual children. Brain Research, 1435, 72-80.

Munoz, C. \& Lindgren, E. (2011): Out-of-school factors: The Home. In: Enever, J. (ed.), ELLiE. Early Language Learning in Europe. London, UK: British Council, 103-122. Available online at: http://www.teachingenglish.org.uk/publications/early-language-learning-europe (02. 04. 2013)

Szpotowicz, M. (2013): Language Achievements of Polish Young Learners. In: Gabrys'-Barker, D., Piechurska-Kuciel, E. \& Zybert, J. (eds.), Investigations in Teaching and Learning Languages, Second Language Learning and Teaching. Springer International Publishing, Switzerland.

Szpotowicz, M. \& Lindgren, E. (2011): Language Achievements. In: Enever, J. (ed.), ELLiE. Early Language Learning in Europe. British Council, London, 125-143.

URL: http://www.teachingenglish.org.uk/publications/early-language-learning-europe (03. 04. 2013)

Tinsley, T. \& Comfort, T. (2012): Lessons from abroad: International review of primary languages. UK: CfBT Education Trust.

URL: http://www.cfbt.com/evidenceforeducation/our_research/evidence_for_government/ international_policy_reforms/published_research_reports/lessons_from_abroad.aspx (02. 04. 2013)

Tragant, E. \& Munoz, C. (2012): Primary school teachers' language practices. A four-year longitudinal study of three FL classes. In: Alcón Soler, E. \& Safont-Jordà, M. (eds.) Discourse and language learning across L2 instructional settings, Utrecht Studies in Language and Communication 24. Utrecht, 8-30.

Vilke, M. (2007): English in Croatia - A glimpse into past, present and future. Metodika, 8. 14, 17-24.

\section{Acknowledgements}

This research was supported by a European Commission grant under the Lifelong Learning Programme (Project number: 135632-LLP-2007-UK-KA1SCR) and by the British Council. This paper is based on work carried out by the whole ELLiE team and their contributions to instrument development, data collection and analysis are gratefully acknowledged. The willingness of the schools, children and parents who allowed us to visit regularly and ask endless questions is also gratefully acknowledged. Without them, this study would not have been possible. Any errors or inaccuracies however, are wholly attributable to the author - for which I offer my sincere apologies. 